\title{
Stress and Work Engagement: Meaningful Work as Mediator
}

\author{
Tuti Rahmi ${ }^{1,2}$, Efi Fitriana ${ }^{1}$, Diana Harding ${ }^{1}$, and Hendriati Agustiani ${ }^{1}$ \\ ${ }^{1}$ Psychology Faculty University of Padjadjaran, Indonesia \\ ${ }^{2}$ Psychology Department of Universitas Negeri Padang, Indonesia \\ *Corresponding Author: tuti18001@unpad.ac.id
}

\begin{abstract}
Background: Work engagement is the antecedent of various outcomes, for instance, performance and well-being. Employees can deeply involve when they have an excellent level of work engagement at work. They become more productive that impacts the organization's benefits and has a positive effect on them. Our study tested whether stress relates negatively to work engagement and if a relationship would be mediated by meaningful work. Method: The research design was a cross-sectional study; 203 participants were included, who work as civil servants and private employees with a minimum education at the undergraduate level. They filled out the scales distributed online. The model was tested used a structural equation model. Result: The result shows a direct negative association between perceived stress and work engagement, a direct negative association between perceived stress and meaningful work, meanwhile a direct positive relationship between meaningful work and work engagement. Henceforward, the structural equation model reveals that meaningful work partially mediated a negative association between perceived stress and work engagement. Conclusion: The study has proved that the empirical evidence of how perceived stress can contribute to work engagement, and in this study, the relationship between the two variables can interfere with meaningful work.
\end{abstract}

Keywords: Stress, meaningful Work, work engagement

\section{INTRODUCTION}

In recent years, rapidly global competition has led many organizations to boost their employees' productivity by increasing their high performance in Indonesia. High performance can be predicted by work engagement. Work engagement shows a direct and positive relationship to performance (Bakker \& Demerouti, 2008). Work engagement is an active and positive state of work demonstrated by dedication, high enthusiasm, and a deep interest in job assignments. Dedication refers to full involvement in his work and experiences a significant, enthusiastic, and challenging experience. High enthusiasm refers to a great level of stamina and resilience at work. Simultaneously, deep interest in work refers to a heightened focus and feeling happy as if lured into his work so that the time goes so fast (Schaufeli \& Bakker, 2004).

Work engagement is a salient concept nowadays. On searches on Google Scholar alone, work engagement shows more than 3.9 million search results. It is different from job satisfaction. Job satisfaction is a more passive formula of employee well-being. It likewise differs from a work-related flow, which functions in performance episodes, which are created by a performance that can even end in an hour or not. Work engagement also differs from a more apparent motivation for dedication to work.
Work engagement is better in predicting performance (Bakker, 2011).

There are at least four explanations why engaged people show better performance than those who are not. First, engaged employees frequently feel encouraging emotions, including gratitude, joy, and enthusiasm. This positive emotion will affect the thoughts and actions that have implications for the employee to work regularly using their resources. Second, engaged employees are healthier to focus well and dedicate all the skills and energy at work. Third, employees who are engaged will build their own personal and work resources. Fourth, engaged employees will transmit their engagement to others (Xanthopoulou, Bakker, Demerouti, \& Schaufeli, 2009). Prior studies show that work engagement has a positive association with quality of life (Mache, Vitzthum, Klapp, \& Danzer, 2014; Selahattin \& Omer, 2012), job satisfaction (Alarcon \& Lyons, 2011; Karanika-Murray, Duncan, Pontes, \& Griffiths, 2015; Mache et al., 2014; Yeh, 2013), happiness (RodríguezMuñoz, Sanz-Vergel, Demerouti, \& Bakker, 2014), life satisfaction (Shimazu \& Schaufeli, 2009). On the contrary, work engagement has a negative relationship with ill health (Shimazu \& Schaufeli, 2009). Generally, work engagement relates to better well-being (Panthee, Shimazu, \& Kawakami, 2014; Scott, Moore, \& Miceli, 
1997; Shimazu, Schaufeli, Kamiyama, \& Kawakami, 2015; Shimazu, Schaufeli, Kubota, \& Kawakami, 2012).

Indonesia is incessantly cheering the essence of work. With the fourth industrial revolution, Indonesia need immediately catch up with other countries. Therefore, work engagement needs to be studied in Indonesia so that the work engagement antecedent could be investigated more and the positive outcome of work engagement of Indonesian employees could be cultivated. A study conducted by Halim (Ayu, Maarif, \& Sukmawati, 2015) illustrates that only $36 \%$ are highly engaged, $17 \%$ feel unengaged, which poses a risk to performance and productivity. The finding exhibits that work engagement among Indonesian employees requires to be improved. So that, The antecedence of work engagement needs to be investigated among Indonesian employees.

There are personal and organizational factors that can affect work engagement. One of the personal features associated with work engagement is stress. The previous studies revealed that stress is negatively related to work engagement (Fiabane, Giorgi, Sguazzin, \& Argentero, 2013; Padula et al., 2012). Besides, stress can affect the negative outcome that the organization does not expect, such as an intention to leave the job, absenteeism rate, withdrawal from work (McKee, Markham, \& Scott, 2004) and can cause an impact on employee's mental and physical health (Ganster \& Rosen, 2013). According to Cohen, stress is the gradation to conditions in a person's life are considered demanding. Perceived Stress consists of perceived helplessness and perceived inefficacy (Örücü \& Demir, 2009). Perceived stress prospectively forecasts psychological symptoms, physical symptoms, and health behavior. Individuals consider circumstances in their lives as stressful (Cohen, 1986).

Meaningfulness or meaningful work refers to work experience, specifically by someone who significantly holds more positive meaning (Rosso, Dekas, \& Wrzesniewski, 2011). Steger, Dik, \& Duffy (2012) posit a concept of meaningful work consisting of three dimensions, i.e., positive meaning, meaningmaking through work, and greater good motivation. Positive meaning is a direct reflection of psychological meaningfulness. Meaning-making through Work, Work is a crucial basis of meaning in life as a whole. Meaningful work can help individuals develop their consideration of themselves and the world around them, enabling their personal development. This aspect helps capture people's work's broader life context (Steger \& Dik, 2009). The third aspect of meaningful work is greater good motivation, and the aspiration to flourish a positive influence on the greater virtuous is constantly associated with meaningful work experiences.
As a mediator, meaningful work has been studied by several scholars. Ahmed et al. (2018) examined how Meaningful work moderately mediating the association between career growth occasions and work engagement. Pradhan \& Pradhan (2016) studied that meaningful work moderately mediating the association between transformational leadership and affective organizational commitment and contextual performance. Arnold, Turner, Barling, Kelloway, \& McKee (2007) examined The association between transformational leadership and psychological well-being fully mediated after controlling for humanistic work beliefs. However, so far, there is no research on meaningful work as a mediator between stress and work engagement. Regarding the previous explanation, this study studied the effect of mediating meaningful work in the association between stress and work engagement.

\section{METHOD}

Sample and Procedure

A quantitative, cross-sectional study was conducted. Two hundred thirty-five employees work in Indonesia's private and public sector and filled out the scale and informed consent distributed online through a social media platform. Only 203 respondents who work more than two years were eligible for the study. Employees who have a part-time job and occupy the highest management position were excluded. Respondents also received information about the study, including how data was collected, stored and confidentiality guarantees before agreeing to informed consent.

Measures

Utrecht Work Engagement Scale (UWES) short version (9 items) was used to measure Work Engagement. Work engagement dimensions are vigor, dedication, and absorption. The Scale of UWES was recorded on a 5-point Likert scale ranging from 1 ("never") to 5 (always"). The UWES has been validated by Rahmadani, Schaufeli, Ivanova, \& Osin (2019) in the Indonesian context with Cronbach alpha 0.87. the Cronbach alpha for this research was 0.890 .

Perceived Stress Scale (PSS; Cohen \& JanickiDeverts, 2012) was used to assess individuals who sensed stress at work. There is ten items. Respondents answered on a 5-point Likert-type scale alternating from never to very often. Saraswati, (2017) translated the PSS. For this research, the reliability coefficient was 0.910 , but no item was eliminated.

The research used the Indonesian version of The Work and Meaning Inventory (WAMI) (Steger et al., 2012) to measure how respondents felt their work is meaningful. Three dimensions of meaningful work are positive meaning, meaning-making, and greater good 
motivations. Participants answered on a 5-point, alternating from 1 (absolutely untrue) to 5 (absolutely true). The researchers adapted the scale; the Cronbach's alpha for this research was 0.893 .

\section{Data Analysis}

Descriptive data denote respondents' sociodemographic, like gender, age, tenure, while the Standard deviation and Mean were depicted. Correlation between variables was tested using Pearson Correlation. Furthermore, the data analysis used SEM, with work engagement as the independent variable, perceived stress as a dependent variable, and meaningful work as a mediator. The data were tested using Lisrel 8.80.

\section{RESULTS}

Regarding table 1, it can be seen that from 203 research respondents, there were relatively equal numbers of men and women, but women were slightly more than men. Most respondents were in the age range less than 35 years, followed by the age range $36-45$ years, whereas based on education at most at the undergraduate level, followed by postgraduate. The details can be shown in table 1 .

Tabel 1. The characteristic demographic profile of respondents $(\mathrm{N}=203)$

\begin{tabular}{llcc}
\hline & Variable & $N$ & $\%$ \\
\hline Gender & & & \\
\hline & Male & 93 & 45.81 \\
\hline Age & Female & 110 & 54.19 \\
\hline & Less Than 35 & 94 & 46.31 \\
\hline & $36-45$ & 89 & 43.84 \\
\hline & 46 and over & 20 & 9.85 \\
\hline Education & & & \\
\hline & & 63.55 \\
\hline & Undergraduate & 36.45 \\
\hline & Postgraduate & 129 & 21.18 \\
\hline Length of Work & Less Than five year & 74 & 29.06 \\
\hline & Less Than ten year & 43 & 29.56 \\
\hline & Less Than 15 year & 59 & 12.32 \\
\hline & Less Than 20 year & 60 & 7.88 \\
\hline 20 years and over & 25 & 37.44 \\
\hline Employee Status & Civil Servant & 16 & 62.56 \\
\hline & Private Employee & 76 & \\
\hline
\end{tabular}

Note: $n=203$

Regarding the length of the work, most have worked for a period of 11-15 years, as many as 60 people or $29.56 \%$, followed by a range of 6-10 years, 59 people or 29.06 , less than five years, 43 people or $21.18 \%$, a range of 16- 20 years as many as 25 people or $12.32 \%$.
Furthermore, regarding employee status, 127 people are not non-civil servants or $62.56 \%$. The descriptive statistic results showed in table 2 that the work engagement means of 3.83 is the same as meaningful work, and perceived stress has a mean of 2.55 .

Tabel 2. Descriptive statistics of measured variables

\begin{tabular}{lccccc}
\hline \multicolumn{1}{c}{ Variables } & Mean & SD & 1 & 2 & 3 \\
\hline 1. Perceived Stress & 2.55 & 0.60 & & & \\
2. Meaningful Work & 3.83 & 0.59 & $-0.344^{* *}$ & & \\
3. Work Engagement & 3.83 & 0.60 & $-0.402^{* *}$ & $0.640^{* *}$ & \\
\hline
\end{tabular}

Note: $* * p<0.05$ level

The Pearson correlation results show a significant and negative association between perceived stress and meaningful work and a significant and negative association between perceived stress and work 
engagement. Meanwhile, a positive and significant association exists between meaningful work and work engagement.

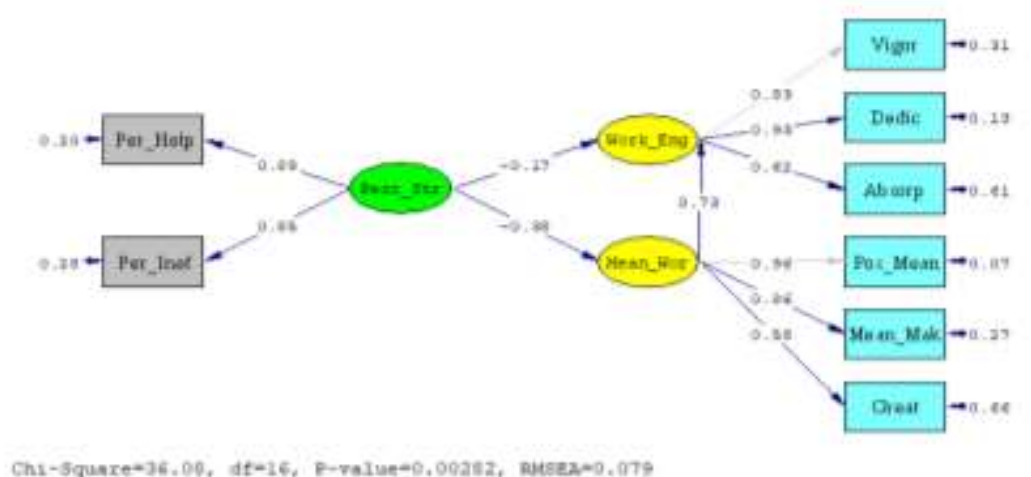

Fig.1. Perceived stress and work engagement as mediated by meaningful work.

Figure 1 demonstrates the model of the relationship between perceived stress and work engagement partially mediated by meaningful work.
There is still a negative and significant association between perceived stress and Work engagement when meaningful work functions as a mediator.

Table 3. The mediating Testing of the Variable

\begin{tabular}{ccc}
\hline The Mediating Testing & Value & Conclusion \\
\hline Perceived Stress-Work Engagement & $-2.02>-1.96$ & Negative and significant \\
Meaningful Work-Work Engagement & $10.47>1.96$ & Positive and significant \\
Perceived Stress-Work Engagement & $-5.12>-1.96$ & Negative and significant \\
\hline
\end{tabular}

The following result of data processing is the model fit test. Regarding several indicators of the existing model fit, it can be said that the measuring instrument is fit because the results of 11 current indicators are already ten indicators that have been met. The results are as follows in table 4.

Table 4. The Goodness of Fit Test Index

\begin{tabular}{lc}
\hline \multicolumn{1}{c}{ The goodness of Fit Test } & Conclusion \\
\hline $\begin{array}{l}\text { Normal Theory Weighted Least Squares Chi-Square =36.08 }(\mathrm{P}=0.002) \\
\text { RMSEA }=0.079\end{array}$ & $\begin{array}{c}\text { No Fit } \\
\text { Medium Fit } \\
\text { NFI }=0.97\end{array}$ \\
Good Fit \\
CFI $=0.98$ & Good Fit \\
RFI $=0.98$ & Good Fit \\
RFI $=0.95$ & Good Fit \\
Standardized RMR $=0.042$ & Good Fit \\
AGFI $=0.90$ & Good Fit \\
\hline
\end{tabular}

\section{DISCUSSION}

Regarding the result, organizations have to pay attention to employee's meaningful work. When employees feel stressed, their meaningful work will mediate their work engagement, and meaningful work is essential as a mediator function, how employees assess situations and conditions that make them feel stressed impacts their meaningful work, followed by work engagement as an outcome. Therefore, meaningful work shows the role that partially affects the association between perceived stress and work engagement. How 
meaningful work mediates the relation between perceived stress and work engagement of the employees depicted in figure 1 . The mediating testing of the structural model is explained in table 3.

The study shows an association between stress and work engagement and meaningful work mediating the relationship between the variables. As projected, the straight correlation between perceived stress and work engagement was proven. This finding shows that the lower a person's stress, the higher their work engagement. Vice versa It also demonstrated that how the employee perceived stress relates to work engagement. This finding is aligned with the previous studies that stress is negatively linked with work engagement. The survey conducted by Fiabane, Giorgi, Sguazzin, \& Argentero (2013) shows the same results in Indonesia. Occupational stress related to work engagement in professional healthcare groups also indicates that organizational and personal factors also play a role in predicting work engagement. The sample of the cross-sectional study was 198 hospital staff. The data gathered by self-report questionnaires. The research shows the highest levels of occupational stress and disengagement of physiotherapists. At the same time, nurse assistants with positive perceived of the work environment were the most work-engaged and job-satisfied. Padula et al. (2012) led research that investigated the association between occupational stress and work engagement. The respondents were 457 male and female employees of the metallurgical industry. The study showed a correlation between occupational stress and work engagement. The mode individuals deal with their frustrations or work engagement is associated with occupational stress.

This finding also identified that perceived stress creates meaningful work, and meaningful work also predicts work engagement. This study is aligned with some researches which sets meaningful work as a mediator. Ahmed et al. (2018) led a survey of 320 employees occupied in the four retail banks in Perlis, Kedah, Penang, Perak, and Terengganu proved meaningful work has the role of mediator in the association between career growth opportunities and work engagement. Pradhan \& Pradhan (2016) investigated meaningful work roles included a sample of 480 IT professionals in India. The study revealed the association between transformational leadership and organizational commitment and contextual performance partially mediated by meaningful work. Affective

One limitation of the study is that all variables of this study are measured by self-report. The measurement can impact social desirability biases and response distortion due to the faking good of the respondent. On the other hand, the study's respondents varied from various provinces and organizations in Indonesia, from private and government organizations. Future research can be studied in specific organizations. It can be investigated in gender-based on stress and meaningful work, and the impact on work engagement.

\section{CONCLUSIONS}

In conclusion, this study has provided empirical evidence for the concept of how perceived stress can contribute to work engagement and how meaningful work can interfere. The study's implication suggests that the organization should be concerned about their employees' stress levels because high-stress levels can affect work engagement. Meanwhile, meaningful work can interfere with the relation, and the employer should develop it to reduce the contribution of stress to work engagement.

\section{REFERENCES}

[1] Ahmed, U., Awang, Z. Bin, Mahmudul, A. S. M., Siddiqui, H. B. A., Dahri, A. S., \& Muda, H. (2018). The Mediating Role of Meaningful Work between Career Growth Opportunities and Work Engagement. International Journal of Academic Research in Business and Social Sciences, 8(11). https://doi.org/10.6007/ijarbss/v8-i11/5168

[2] Alarcon, G. M., \& Lyons, J. B. (2011). The relationship of engagement and job satisfaction in working samples. Journal of Psychology: Interdisciplinary and Applied, 145(5), 463-480. https://doi.org/10.1080/00223980.2011.584083

[3] Arnold, K. A., Turner, N., Barling, J., Kelloway, E. K., \& McKee, M. C. (2007). Transformational leadership and psychological well-being: The mediating role of meaningful work. Journal of Occupational Health Psychology, 12(3), 193-203. https://doi.org/10.1037/1076-8998.12.3.193

[4] Ayu, D. R., Maarif, S., \& Sukmawati, A. (2015). Pengaruh Job Demands, Job Resources Dan Personal Resources Terhadap Work Engagement. Jurnal Aplikasi Bisnis Dan Manajemen, 1(1), 12 22. https://doi.org/10.17358/JABM.1.1.12

[5] Bakker, A. B. (2011). An Evidence-Based Model of Work Engagement. Current Directions in Psychological Science, 20(4), 265-269. https://doi.org/10.1177/0963721411414534

[6] Bakker, A. B., \& Demerouti, E. (2008). Towards a model of work engagement. Career Development International, 13(3), 209-223. https://doi.org/10.1108/13620430810870476

[7] Cohen, S. (1986). Contrasting the Hassles Scale and the Perceived Stress Scale. Who's Really Measuring Appraised Stress? American Psychologist, 41(6), 716-718. https://doi.org/10.1037/0003066X.41.6.716 
[8] COHEN, S., \& JANICKI-DEVERTS, D. (2012). Who's Stressed? Distributions of Psychological Stress in the United States in Probability Samples from 1983, 2006, and 20091. Journal of Applied Social Psychology, 42(6), 1320-1334. https://doi.org/10.1111/j.1559-1816.2012.00900.x

[9] Dwi, K., \& Saraswati, H. (2017). Perilaku Kerja , Perceived Stress, dan Social Support pada Mahasiswa Internship. Jurnal Muara Ilmu Sosial, Humaniora, Dan Seni, 1(1), 216-222.

[10] Fiabane, E., Giorgi, I., Sguazzin, C., \& Argentero, P. (2013). Work engagement and occupational stress in nurses and other healthcare workers: The role of organisational and personal factors. Journal of Clinical Nursing, 22(17-18), 2614-2624. https://doi.org/10.1111/jocn. 12084

[11] Ganster, D. C., \& Rosen, C. C. (2013). Work Stress and Employee Health: A Multidisciplinary Review. Journal of Management, 39(5), 1085-1122. https://doi.org/10.1177/0149206313475815

[12] Karanika-Murray, M., Duncan, N., Pontes, H. M., \& Griffiths, M. D. (2015). Organizational identification, work engagement, and job satisfaction. Journal of Managerial Psychology, 30(8), 1019-1033. https://doi.org/10.1108/JMP-112013-0359

[13] Mache, S., Vitzthum, K., Klapp, B. F., \& Danzer, G. (2014). Surgeons' work engagement: Influencing factors and relations to job and life satisfaction. Surgeon, 12(4), 181-190. https://doi.org/10.1016/j.surge.2013.11.015

[14] McKee, G. H., Markham, S. E., \& Scott, K. D. (2004). Job stress and employee withdrawal from work. Stress \& Well-being at Work: Assessments and Interventions for Occupational Mental Health., 153-163. https://doi.org/10.1037/10116-010

[15] Örücü, M. Ç., \& Demir, A. (2009). Psychometric evaluation of perceived stress scale for Turkish university students. Stress and Health, 25(1), 103109. https://doi.org/10.1002/smi.1218

[16] Padula, R. S., Chiavegato, L. D., Cabral, C. M. N., Almeid, T., Ortiz, T., \& Carregaro, R. L. (2012). Is occupational stress associated with work engagement? Work, 41(SUPPL.1), 2963-2965. https://doi.org/10.3233/WOR-2012-0549-2963

[17] Panthee, B., Shimazu, A., \& Kawakami, N. (2014). Validation of Nepalese version of Utrecht work engagement scale. Journal of Occupational Health, 56(6), 421-429. https://doi.org/10.1539/joh.140041-OA

[18] Pradhan, S., \& Pradhan, R. K. (2016). Transformational Leadership and Job Outcomes: The Mediating Role of Meaningful Work. Global
Business Review, 17, 173S-185S. https://doi.org/10.1177/0972150916631211

[19] Rahmadani, V. G., Schaufeli, W. B., Ivanova, T. Y., \& Osin, E. N. (2019). Basic psychological need satisfaction mediates the relationship between engaging leadership and work engagement: A cross-national study. Human Resource Development Quarterly. https://doi.org/10.1002/hrdq.21366

[20] Rodríguez-Muñoz, A., Sanz-Vergel, A. I., Demerouti, E., \& Bakker, A. B. (2014). Engaged at Work and Happy at Home: A Spillover-Crossover Model. Journal of Happiness Studies, 15(2), 271283. https://doi.org/10.1007/s10902-013-9421-3

[21] Rosso, B. D., Dekas, K. H., \& Wrzesniewski, A. (2011). Corrigendum to "On the meaning of work: A theoretical integration and review" [Res. Organ. Behav. 30 (2010) 91-127]. Research in Organizational Behavior, 31, 277. https://doi.org/http://dx.doi.org/10.1016/j.riob.201 1.10 .001

[22] Schaufeli, W. B., \& Bakker, A. B. (2004). Job demands, job resources, and their relationship with burnout and engagement: a multi-sample study. Journal of Organizational Behavior, 25(3), 293315. https://doi.org/10.1002/job.248

[23] Scott, K. S., Moore, K. S., \& Miceli, M. P. (1997). An exploration of the meaning and consequences of workaholism. Human Relations, 50(3), 287-314. https://doi.org/10.1177/001872679705000304

[24] Selahattin, K., \& Omer, S. (2012). An Empirical Research on Relationship Quality of Work Life and Work Engagement. Procedia - Social and Behavioral Sciences, 62, 360 citation_lastpage=6.

[25] Shimazu, A., \& Schaufeli, W. B. (2009). Is workaholism good or bad for employee well-being? The distinctiveness of workaholism and work engagement among Japanese employees. Industrial Health, 47(5), 495-502 https://doi.org/10.2486/indhealth.47.495

[26] Shimazu, A., Schaufeli, W. B., Kamiyama, K., \& Kawakami, N. (2015). Workaholism vs. Work Engagement: the Two Different Predictors of Future Well-being and Performance. International Journal of Behavioral Medicine, 22(1), 18-23. https://doi.org/10.1007/s12529-014-9410-x

[27] Shimazu, A., Schaufeli, W. B., Kubota, K., \& Kawakami, N. (2012). Do workaholism and work engagement predict employee well-being and performance in opposite directions? Industrial Health, 50(4), 316-321. https://doi.org/10.2486/indhealth.MS1355

[28] Steger, M. F., \& Dik, B. J. (2009). If One is Looking for Meaning in Life, Does it Help to Find Meaning 
in Work? Applied Psychology: Health and WellBeing, 1(3), 303-320. https://doi.org/10.1111/j.1758-0854.2009.01018.x

[29] Steger, M. F., Dik, B. J., \& Duffy, R. D. (2012). Measuring Meaningful Work: The Work and Meaning Inventory (WAMI). Journal of Career Assessment, 20(3), 322-337. https://doi.org/10.1177/1069072711436160

[30] Xanthopoulou, D., Bakker, A. B., Demerouti, E., \& Schaufeli, W. B. (2009). Reciprocal relationships between job resources, personal resources, and work engagement. Journal of Vocational Behavior, 74(3),

235-244. https://doi.org/10.1016/j.jvb.2008.11.003

[31] Yeh, C. M. (2013). Tourism involvement, work engagement and job satisfaction among frontline hotel employees. Annals of Tourism Research, 42, 214-239.

https://doi.org/10.1016/j.annals.2013.02.002 